\title{
Social Capital that Affects the Forming of Entrepreneurial Intention through Self-Efficacy
}

DOI: https://doi.org/10.47175/rissj.v2i4.288

\begin{tabular}{|c|c|}
\hline Nurhidayani $^{1, *} \mid$ Trisn & Martono ${ }^{2}$ | Dewi Kusuma Wardani ${ }^{3}$ | \\
\hline $\begin{array}{l}\text { 1,2,3Faculty of Economics } \\
\text { Education, Sebelas Maret } \\
\text { University, Surakarta, } \\
\text { Indonesia } \\
{ }^{*} \text { nurhidayani_nurhidayani@stu } \\
\text { dent.uns.ac.id }\end{array}$ & $\begin{array}{l}\text { ABSTRACT } \\
\text { Understanding the various factors that influence entrepreneurial } \\
\text { intentions is very important in efforts to develop entrepreneurship } \\
\text { in higher education. Entrepreneurship is currently the center of } \\
\text { attention of various parties because it has a contribution to } \\
\text { economic development that can be used to overcome the problem } \\
\text { of the gap between job opportunities and the available workforce } \\
\text { for young people. This study investigates the role of social capital } \\
\text { on entrepreneurial intentions and other variables that may } \\
\text { mediate the relationship between the two. For this purpose, using } \\
\text { a sample of } 269 \text { students majoring in education last year at the } \\
\text { Sebelas Maret University. Using structured questionnaire in data } \\
\text { collection, and tested with SPSS. the results obtained from the } \\
\text { collected data indicate that social capital has a direct and indirect } \\
\text { influence on entrepreneurial intentions through self-efficacy. } \\
\text { KEYWORDS } \\
\text { education; entrepreneurial intention; social capital; self-efficacy }\end{array}$ \\
\hline
\end{tabular}

\section{INTRODUCTION}

Currently, various countries in the world view entrepreneurship as an important attribute that plays a role in the dynamics of the modern economy. This is because entrepreneurship is the main source of creating new jobs that will have an impact on poverty alleviation (Ali $\&$ Yousuf, 2019). According to Mayer (2014) believes that in the case of unemployment among higher education graduates, entrepreneurship development programs can create a culture to become entrepreneurs. This will help reduce youth unemployment in developing countries and help promote economic development.

Entrepreneurial activity can be considered as a social process that is embedded in a network of one's relationship attachment as the implementation of effective communication (McKeever, Anderson, \& Jack, 2014). Through this social network, also supports the efforts made by novice entrepreneurs by facilitating and improving their business performance. The emergence of the creation of this new business can occur because of the intention of the entrepreneur. Therefore, all entrepreneurial activity that occurs can be considered as a planned behavior However, a person's intention to start a business can be influenced by many factors, including social capital which is considered to be one of the key factors that influence individual entrepreneurial attitudes among many other factors. To be an entrepreneur is not as easy as many people think. There are various challenges that must be faced by every entrepreneur, from small things to big things (Tambunan, 2021).

According to Malebana (2019), there are various definitions of social capital from researchers including defining social capital based on its relationship with social networks. His argument states that social networking is considered very important to contribute to building social capital. Because they are the result of social relationships created and maintained through reciprocal relationships in social processes or what is often referred to 
as social interaction. The importance of this social network at all stages of the business life cycle where this process can help provide a variety of social support and insights for entrepreneurs from before starting the business to the stage when the business is founded and when the business is stable.

Previous research on social capital has shown that social capital influences students' entrepreneurial intentions (Mahfud, Triyono, Sudira, \& Mulyani, 2020). Social capital also plays a role in influencing someone to choose entrepreneurship as the option to choose a career, which will especially increase interest after receiving firsthand experience and exposure from successful entrepreneurs. this can contribute to the creation of inspiration (Dohse \& Walter, 2012). Social capital will provide clear information knowledge and experience to increase the possibility for someone to become a new entrepreneur. Broadly speaking, New entrepreneurs who will enter the business process are individuals who are involved in organizing and gathering the resources they need to start their business.

In addition, efforts to develop entrepreneurial intentions also require self-confidence or commonly called self-efficacy. According to Bandura (1998), Self-efficacy is the belief that one of the skills possessed by an individual can be used to perform certain actions. Self-efficacy is needed because it is related to self-confidence and control in every event that will have an impact on his life. Luthans \& Ibrayeva, (2006) states that self-efficacy is a variable that has a direct and mediating influence on entrepreneurial intentions.

This study seeks to explain the role of social capital in encouraging entrepreneurship at one of the universities in Indonesia. This type of research will stimulate the desire of higher education graduates to become entrepreneurs. thus, assisting the process of entrepreneurship development and the application of appropriate policies to stimulate entrepreneurial activity. The aim is to determine the influence of social effects, namely social capital with entrepreneurial intentions on students who will soon graduate using social cognitive theory.

\section{RESEARCH METHODS}

Social capital is a suitable strategy to motivate students to become entrepreneurs. Vukovi, Kedmenec, Postolov, Jovanovski, \& Korent, (2017) mentioned that social capital significantly affects entrepreneurship. New entrepreneurs often feel unable to realize business ideas because of concerns and inability to obtain capital. Through entrepreneurial knowledge will help provide solutions with experience to receive information and get relationships to share and collaborate to start a business.

\section{H1: Effect of Social Capital on Entrepreneurial Intention}

Self-efficacy is a person's belief in his ability to do something he wants, the belief to be able to be an entrepreneur requires knowledge of entrepreneurship. Social capital is one part of environmental factors, where environmental factors play a role in increasing selfefficacy (Sari \& Riau, 2020). Social capital also helps provide an overview of experiences from various relationships and creates confidence in starting a business.

Through the above information raises the suspicion that social capital affects student selfefficacy.

\section{H2: Effect of Social Capital on Self-Efficacy}

Self-efficacy is an intrinsic factor that can affect interest in entrepreneurship. Self-efficacy is a motivation for someone because of their self-confidence and belief in their abilities. A person's perception of self-efficacy has a strong influence on their actions and how knowledge, skills will be used. Self-efficacy will encourage a person's performance in 
various fields, including an interest in entrepreneurship. according to (Farida \& Nurkhin, 2016) states, self-efficacy influences interest in entrepreneurship

\section{H3: Effect of Efficacy on Entrepreneurial Intention}

Entrepreneurial intention is the impetus for every individual to start entrepreneurship. Selfefficacy provides confidence and determination and eliminates worry about risks in entrepreneurship. The confidence that individuals have for entrepreneurship can be seen from the level of readiness for planning the business to be run. Social capital provides understanding and support indirectly through observation and mutual care through achieving goals. Through the information above, it is suspected that social capital will affect entrepreneurial intentions through self-efficacy.

\section{H4: Indirect Effect of Social Capital on Entrepreneurial Intention}

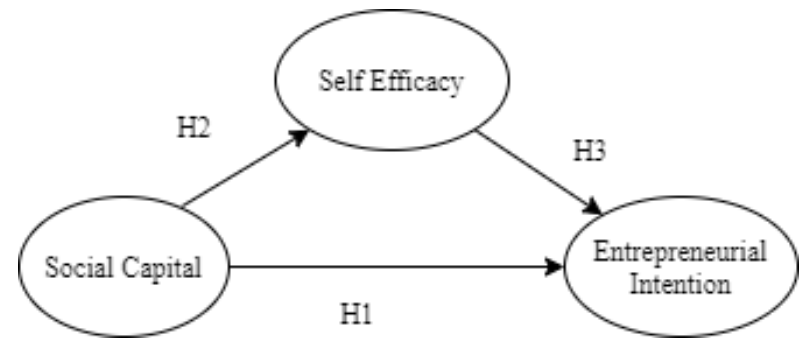

Figure 1. Research Model

Based on the objectives, this research uses hypothesis testing research using a quantitative descriptive. All students majoring in education at Sebelas Maret University are the population who had taken the final semester. The number of samples used was 269 students. The research sample was taken using proportionate stratified random sampling, which is random sampling with proportional stratified sampling. This method is done because there are elements that are not homogeneous in the sample but are proportionally stratified.

This study using uses data analysis techniques through the ANOVA test through the SPSS statistical application program. Based on what has been explained by Sugiyono (2014) The variable that is used this time is the use of the independent variable, there is social capital, the dependent variable is entrepreneurship intention and the intervening variable is self-efficacy.

Table 1. Operational Definition of Variables

\begin{tabular}{|c|c|c|}
\hline Variable & Operational definition & Indicator \\
\hline $\begin{array}{l}\text { Entrepreneurial } \\
\text { intention }\end{array}$ & $\begin{array}{l}\text { Entrepreneurial intention is a sense of } \\
\text { interest in someone to start a business by } \\
\text { taking advantage of the opportunities that are } \\
\text { around him. (Purnomo, 2005) }\end{array}$ & $\begin{array}{ll}\text { 1. } & \text { Self-confident } \\
\text { 2. } & \text { Task and result oriented } \\
\text { 3. } & \text { Risk-Taking } \\
\text { 4. } & \text { Leadership } \\
\text { 5. } & \text { Originality }\end{array}$ \\
\hline Social capital & $\begin{array}{l}\text { Social capital is a relationship that is built } \\
\text { from various social structures that involve } \\
\text { various parties(Coleman, 1988) }\end{array}$ & $\begin{array}{l}\text { 1. Structural Dimension } \\
\text { 2. Relational dimension } \\
\text { 3. Cognitive dimension }\end{array}$ \\
\hline Self-efficacy & $\begin{array}{l}\text { Self-efficacy is the belief in one's ability to } \\
\text { be used to organize and perform a series of } \\
\text { actions to achieve all that is desired. } \\
\text { (Bandura, 1986) }\end{array}$ & $\begin{array}{ll}\text { 1. } & \text { Magnitude } \\
\text { 2. } & \text { Strength } \\
\text { 3. } & \text { Generality }\end{array}$ \\
\hline
\end{tabular}




\section{RESULTS AND DISCUSSION}

The quality test carried out in the research instrumental test used confirmatory factor analysis (CFA). This test analysis is used to validate element indicators that represent latent constructs. In addition, confirmatory factor analysis (CFA) is also used to measure the extent to which the indicators used in the study can determine what is calculated. The following is the validity test data obtained in testing all instruments measuring these indicators, it can be seen that the validity value obtained is between 0.550 to 0.888 .

On the social capital variable 1 worth 0.822 , social capital 2 worth 0.714 , social capital 3 worth 0.843 . The self-efficacy variable 1 is worth 0.777 , self-efficacy 2 is 0.660 , selfefficacy 3 is 0.550 . In the variable entrepreneurial intention 1 worth 0.881 , entrepreneurial intention 2 worth 0.865 , entrepreneurial intention 3 worth 0.851 , entrepreneurial intention 4 worth 0.888 , and entrepreneurial intention 5 worth 0.835 . This illustrates that the indicators that have been tested are valid because they have met the requirements for factors weighing above 0.5. according to toGhozali and Latan, (2015) states that the 0.5 limit is already a limit for the value of convergent validity

In addition to the validity test, the reliability test was also carried out to measure the level of consistency of the instrument. Reliability tests can be interpreted as trust, reliability, and consistency. The results of measurement will be reliable if several times the measurement is obtained the same value. The reliability test results obtained have a reliability value above 0.70 . These data are on the social capital variable of 0.870 , selfefficacy 0.756 , and entrepreneurship intention of 0.900 . The result of the variable instrument used has a value of more than 0.70. according to Ghozali and Latan (2015) mentions the limit value used in measuring the level of reliability, which is 0.70 . This means that all variables are said to be reliable. so that it can be continued in the next test.

Table 2. Validity and Reliability Test

\begin{tabular}{|c|c|c|c|}
\hline Indicator & Validity & \multirow{12}{*}{ 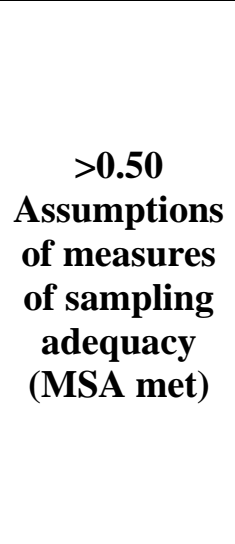 } & Reliability \\
\hline Social Capital1 & 0.822 & & \multirow{3}{*}{0.870} \\
\hline Social Capital2 & 0.714 & & \\
\hline Social Capital3 & 0.843 & & \\
\hline Self efficacy 1 & 0.777 & & \multirow{3}{*}{0.756} \\
\hline Self-efficacy 2 & 0.664 & & \\
\hline Self-efficacy3 & 0.550 & & \\
\hline Entrepreneurial intention1 & 0.881 & & \multirow{5}{*}{0.900} \\
\hline Entrepreneurial intention2 & 0.865 & & \\
\hline Entrepreneurial intention3 & 0.851 & & \\
\hline Entrepreneurial intention4 & 0.888 & & \\
\hline Entrepreneurial intention5 & 0.835 & & \\
\hline
\end{tabular}

The normality test aims to test whether, in the regression model, the confounding or residual variables have a normal distribution. A good regression model has a normal or close to normal distribution. In the normality test, it can be seen that the Asymp value. Sig. (2-tailed) of 0.759. in decision making, if the significance value is $>0.05$, then the residual value is normally distributed. The result is $0.759>0.05$ then the residual has a normal distribution.

Table 3. Normality test

\begin{tabular}{|l|c|}
\hline & $\begin{array}{c}\text { Unstandardized } \\
\text { Residual }\end{array}$ \\
\hline $\mathrm{N}$ & 269 \\
\hline Kolmogorov-Smirnov Z & 0.671 \\
\hline asymp. Sig. (2-tailed) & 0.759 \\
\hline
\end{tabular}


Table 4. Hypothesis Test

\begin{tabular}{|l|l|l|l|l|}
\hline & $\begin{array}{l}\text { Standardized } \\
\text { Coefficients Beta }\end{array}$ & Sig & $\begin{array}{l}\text { R } \\
\text { Square }\end{array}$ & e' \\
\hline Social Capital (M) -> Self Efficacy (E) & 0.687 & 0.000 & 0.470 & 0.726 \\
\cline { 1 - 3 } $\begin{array}{l}\text { Social Capital (M)-> Entrepreneurial } \\
\text { Intention(N) }\end{array}$ & 0.191 & 0.000 & 0.627 & 0.611 \\
\cline { 1 - 3 } $\begin{array}{l}\text { Self Efficacy (E)-> Entrepreneurial } \\
\text { Intention (N) }\end{array}$ & 0.648 & 0.000 & & \\
\hline
\end{tabular}

\section{The Effect of Social Capital on Entrepreneurial Intention}

In entrepreneurship, of course, one must have a high intention to be able to manifest himself as an entrepreneur. Entrepreneurial intention itself is a desire in oneself to start entrepreneurship. Someone who wants his business to grow must have good social capital. Social capital is a person's ability to find and maintain relationships with other people who will become a force in the economy and other aspects of social existence.

Based on the calculation results prove that social capital has a direct and significant influence on entrepreneurial intentions. This is evidenced by the significance value of social capital on entrepreneurial intentions of 0.000 with a beta coefficient of 0.191 which has met the requirements of sig. $<0.05$, which means that $\mathrm{H} 1$ is accepted, that is, there is a direct influence of social capital on entrepreneurial intentions. The coefficient of influence given is small at 0.191 , which means that the effect of social capital is only $19.1 \%$ on entrepreneurial intentions. This means that the higher the social capital owned by students, the higher the entrepreneurial intention of the students with an increase of $19.1 \%$ from the beginning, and does not deny that other variables can affect entrepreneurial intentions with high scores.

\section{The Effect of Social Capital on Self-Efficacy}

Someone who can be trusted has a wide network, and is well behaved of course will have high efficacy because wherever he is, he will feel no difficulty, because there are people around him who will always be ready to help. The results of the study prove that social capital has a direct effect on self-efficacy. This is evidenced by the magnitude of the significant value of social capital on self-efficacy of 0.000 with a beta coefficient of 0.687 then $\mathrm{H} 2$ is accepted, namely the direct influence of social capital on self-efficacy. Based on these data, it shows that the higher students' social capital will increase their self-efficacy by $68 \%$.

\section{The Effect of Self-Efficacy on Entrepreneurial Intentions}

Self-efficacy can encourage a person's performance in various fields including providing entrepreneurial intentions. Therefore, in opening a business, it is necessary to have selfconfidence (self-efficacy) in his abilities so that his business can be successful. The same thing was also expressed by Robbins (2007) self-efficacy is known as socio-cognitive or social reasoning which refers to an individual's belief that he is capable of carrying out a task. The results of this study prove that self-efficacy has a direct effect on entrepreneurial intentions. This is evidenced by the magnitude of the significant value of 0.000 which has met the requirements of sig $<0.05$. The coefficient of influence given is positive at 0.648 , which means the effect of self-efficacy is $64.8 \%$ on entrepreneurial intentions.

\section{Indirect Effect of Social Capital on Entrepreneurial Intention}

Entrepreneurial intention is a belief in every individual to start entrepreneurship. Selfefficacy provides confidence and determination and eliminates worry about risks in 
entrepreneurship. The confidence that individuals have for entrepreneurship can be seen from the level of readiness for planning the business to be run. Social capital provides understanding and support indirectly through observation and mutual care through achieving goals.

Based on the table described above, it can be seen that the indirect role of social capital through self-efficacy on entrepreneurial intentions is 0.636 or contributes $63.6 \%$ with the calculation of the indirect effect coefficients $M->E^{*}$ Coefficients $E->N=(0.687 * 0.648)=$ 0.445 . total direct effect $\mathrm{M}->\mathrm{E}+$ indirect effect $=0.191+0.445=0.636$. The total value of the indirect effect of 0.636 is greater than the direct effect of 0.445 . So that the indirect role of social capital on entrepreneurial intentions through self-efficacy becomes significant. So, $\mathrm{H} 4$ is accepted, that is, there is an indirect effect of social capital on entrepreneurial intentions through self-efficacy.

\section{CONCLUSION}

The indirect relationship between social capital and interest in entrepreneurship through self-efficacy conceptualized in this study is significant and has a higher value than the direct relationship between social capital and interest in entrepreneurship. This research is to increase the interest in entrepreneurship through the strategy of providing knowledge and experience based on building self-efficacy and social capital. Social capital and selfefficacy play important factors in influencing entrepreneurial interest. So in this case the implications for educational institutions to be able to facilitate learning facilities that are humane and experienced to share expertise so that they are more confident to start a business. The stimulus that can be given can be in the form of presenting successful entrepreneurs in learning, assisting business mentoring for startups, business practices, and hands-on management. With self-understanding and experience from others who have been successful, the target of higher education graduates who are entrepreneurship will increase.

Further research can use other variables in measuring entrepreneurial intentions. Based on the data, it can be seen that the social capital variable only contributed 0.191 or only contributed $19.1 \%$ and self-efficacy gave 0.648 . then there are many other variables besides social capital that need to be considered in the formation of entrepreneurial intentions.

\section{REFERENCES}

Ali, A., \& Yousuf, S. (2019). Social capital and entrepreneurial intention: empirical evidence from rural communities of Pakistan. Journal of Global Entrepreneurship Research, 9(1). https://doi.org/10.1186/s40497-019-0193-z

Bandura, A. (1986). The Explanatory and Predictive Scope of Self-Efficacy Theory. Journal of Social and Clinical Psychology. https://doi.org/10.1521/jscp.1986.4.3.359

Bandura, A. (1998). Self-Efficacy. (1994), 1-65.

Coleman, James s. (1988). r.

Dohse, D., \& Walter, SG (2012). Knowledge context and entrepreneurial intentions among students. Small Business Economics, 39(4), 877-895. https://doi.org/10.1007/s11187011-9324-9

Farida, S., \& Nurkhin, A. (2016). The Influence of Entrepreneurship Education, Family Environment, and Self Efficacy on Entrepreneurial Interest of Vocational High School Students in Accounting Expertise Program. Economic Education Analysis Journal, 5(1), 273-289.

Ghozali, I., \& Latan, H. (2015). Partial Least Squares Concepts, Techniques, and 
Applications using the SmartPLS 3.0 Program for Empirical Research. Semarang: UNDIP Press.

Luthans, F., \& Ibrayeva, ES (2006). Entrepreneurial self-efficacy in Central Asian transition economies: quantitative and qualitative analyses. 92-110. Journal of International Business Studies, https://doi.org/10.1057/palgrave.jibs.8400173

Mahfud, T., Triyono, MB, Sudira, P., \& Mulyani, Y. (2020). The influence of social capital and entrepreneurial attitude orientation on entrepreneurial intentions: the mediating role of psychological capital. European Research on Management and Business Economics, 26(1), 33-39. https://doi.org/10.1016/j.iedeen.2019.12.005

Malebana, MJ (2019). The influencing role of social capital in the formation of entrepreneurial intention. Southern African Business Review, 20(1), 51-70. https://doi.org/10.25159/1998-8125/6043

McKeever, E., Anderson, A., \& Jack, S. (2014). Entrepreneurship and mutuality: social capital in processes and practices. Entrepreneurship and Regional Development, 26(56), 453-477. https://doi.org/10.1080/08985626.2014.939536

Meyer, N. (2014). Creating an entrepreneurial culture among students through entrepreneurship development programs (EDP). Mediterranean Journal of Social Sciences, 5(13 SPEC. ISSUE), 281-288. https://doi.org/10.5901/mjss.2014.v5n13p281

Purnomo, BH (2005). Building Entrepreneurial Spirit. Yogyakarta: Laksbang Pressindo.

Sari, PW, \& Riau, UI (2020). Analysis of the factors that influence the entrepreneurship interests of uir students. Analysis of the factors that influence the interests of foreign students. 17(1), 152-162.

Sugiyono. (2014). Research Methodology Quantitative Qualitative R\&D (21st ed.). Bandung: Alphabeta.

Tambunan, F. (2021). The Effect of Business Planning and Record on Entrepreneur Success. Randwick International of Social Science Journal, 2(3), 236-240. https://doi.org/10.47175/rissj.v2i3.261

Vuković, K., Kedmenec, I., Postolov, K., Jovanovski, K., \& Korent, D. (2017). The role of bonding and bridging cognitive social capital in shaping entrepreneurial intention in transition economies. Management (Croatia), 22(1), 1-34. https://doi.org/10.30924/mjcmi/2017.22.1.1 